\title{
INDONESIAN MUSLIMS IN THE PUBLIC SPHERE A Review of Several Studies
}

\author{
Mujiburrahman \\ IAIN Antasari Banjarmasin
}

\begin{abstract}
Habermas' idea of the public sphere as a space where members of society can develop discussions and debates on public issues has inspired some scholars to interpret the modern development of Muslim societies. The spread of communication technology that includes print and electronic media, has paved the way for the emergence of the public sphere in those societies. Several studies of Indonesian Islam by western scholars also pay attention to the public sphere. Having discussed those studies, this paper argues that, although Habermas' very notion of the public sphere has been criticised and modified by the scholars, it can be used effectively and developed for further research on Indonesian Islam.
\end{abstract}

Keywords: Public Sphere, Indonesian Islam, Public Culture, Reasoning.

\section{Introduction}

Habermas' idea of the public sphere-originally discussed in his book on the development of the public sphere in Europe is an important contribution to recent social studies. ${ }^{1}$ What he means by "public sphere" is apparently a space where members of society could develop discussions and debates on public issues face-to-face or through modern media. ${ }^{2}$ The idea of public sphere has inspired some

\footnotetext{
1 Jürgen Habermas, The Structural Transformation of the Public Sphere: An Inquiry into a Category of Bourgeois Society, trans. by Thomas Burger and Frederick Lawrance. (Cambridge: Polity Press, 1989).

2 I fail to find a clear definition of public sphere by Habermas. However, Charles Taylor's following definition is probably helpful: It is "a common space in which members of society are deemed to meet through a variety of media: print, electronic and also face-to-face encounter; to discuss matters of common interest; and thus to be
} 
scholars to understand the modern development of Muslim societies. ${ }^{3}$ According to these scholars, the widespread of communication technology that includes print and electronic media, has paved the way for the emergence of public sphere in Muslim societies.

Some scholars studying Indonesian Islam are also interested in looking at the development of public sphere in the country. In what follows, I will review the existing relevant studies on Indonesian Islam and analyse them through the scholarly critical discussion on Habermas' public sphere. This analysis will hopefully open more possibilities to study Indonesian Islam in a better perspective.

\section{Indonesian Muslim Media}

There are some studies on Muslim media in Indonesia. Only a few of them, however, explicitly employ the idea of public sphere in their analysis. Almost all of the studies pay attention to the media produced by the reformists and hardliners. The latter type of media has attracted some researchers especially since 1990s.

The study of al-Muslimun magazine by Federspiel is probably one of the early studies of modern Muslim media in Indonesia. ${ }^{4}$ The alMuslimun belongs to a reformist Muslim organization called Persatuan Islam that is based in Bandung of West Java. ${ }^{5}$ Compared to another reformist Muslim organization called "Muhammadiyah", Persatuan Islam more strongly promotes the idea of purification of Islam from its syncretic elements and the return to the scripture and the prophetic tradition. ${ }^{6}$ In this study Federspiel concentrates on the issues of the magazine published between 1954 and 1960. The focus of the study is a section of the magazine called "question and answer" (sual-djawab) in which the editors of the magazine answer specific questions from the

able to form a common mind about this." See Charles Taylor, "Modernity and the Rise of the Public Sphere," The Tanner Lectures on Human V alues, 14 (1993), p. 220.

${ }^{3}$ Dale F Eickelman and John Anderson, "Redefining Muslim Publics," in Dale F. Eickelman and John Anderson (eds), New Media in the Muslim World: The Emerging Public Sphere (Bloomington: Indiana University Press, 1999), p. 203.

${ }^{4}$ Howard M Federspiel, "The Political and Social Language of Indonesian Muslims: The Case of al-Muslimun," Indonesia, 38 (1984), pp, 55-73.

${ }_{5}$ Persatuan Islam also has activities in Bangil, East Java.

${ }^{6}$ For a more comprehensive study of the Persatuan Islam, see Howard M. Federspiel, Islam and Ideology in the Emerging Indonesian State: the Persatuan Islam (PERSIS) 1923-1957 (Leiden: Brill, 2001).. 
readers regarding religious matters. In other words, the "question and answer" section is actually a place for giving fatwas?

In Federspiel's description of the contents of the question and answer section we find that there are some fatwa thallenging the existing Islamic traditional practices, such as the fatwa $\rightarrow$ n the practice of instructing the deceased to help the person answer the questions of Angels on religious beliefs in a funeral ritual called "talqin," and the holding of the ritual meal (slametan) during an eclipse of the moon. According to the editors of the magazine, these practices are unacceptable accretions (bid'ah). The magazine also discusses how Muslims should interact with other identified groups: the Jews and the Christians (abl al-kitäb), the Chinese, the Communists and the Nationalists. Most of the attitudes prescribed by the magazine are friendly and tolerant except to the communists because "the Communist Party is dedicated to principles that are anti-religious and against Islam." 7 However, Federspiel does not further elaborate this interaction. This leads us to question: what was the response of the traditionalist religious authorities to the challenge prompted by alMuslimun? Was there any discussion and debate between these two groups in seminars and print media? Was there any reaction of the Christians, the Chinese, the Communists and the Nationalists to the position taken by al-Muslimun? It seems that these questions do not bother Federspiel because his purpose in the article is not to see public discussions and debates illustrated by the magazine but only to show that there is a pure and non-syncretic Islamic discourse in Indonesia. ${ }^{8}$

Unlike Federspiel's study, the later studies of Muslim media try to see the position of the opponent of the media in question. Liddle's article on Media Dakwah magazine' and Hefner's study of Media Dakwah versus Republika ${ }^{10}$ clearly demonstrate how opposite

\footnotetext{
${ }^{7}$ Federspiel, "The Political and Social Language," p. 66.

8 Ibid, p. 55.

9 William R. Liddle, "Media Dakwah Scripturalism: One Form of Islamic Political Thought and Action in New Order Indonesia," in Mark R. Woodward (ed.), Toward a New Paradigm: Recent Developments in Indonesian Islamic Thought (Tempe: Arizona State University, 1996).

10 Robert W Hefner, "Print Islam: Mass Media and Ideological Rivalries among Indonesian Muslims,” Indonesia, 64 (1997), pp. 77-103.
} 
interpretations of Islam and their political contexts have been reflected in the media. ${ }^{11}$ In his article, Liddle discusses two opposite interpretations of Islam in Indonesia. He categorizes them as the 'substantialist' versus the 'scripturalist.' The former refers to the renewal movement pioneered by Nurcholish Madjid since $1970 \mathrm{~s}^{12}$ while the latter refers to Media Dakwah and its proponents. According to Liddle, the substantialist group holds the idea that faith and ethics are more important than formal adherence to Islam. Therefore, this group is more open and tolerant to differences and reject the necessity of founding an Islamic state. The scripturalist group, on the other hand, aspires to the idea of Islamic state and considers those who disagree with them as the enemies of Islam. Apart from the fact that Liddle's dichotomy has been criticized of being rather simplistic, ${ }^{13}$ it helps understand the Media Dakwah's account of its opponents.

In his discussion, Liddle traces the socio-political background of the contest between the substantialist and the scripturalist. Media Dakwah is a monthly magazine published by Dewan Dakwah Islamiyah Indonesia (DDII/Indonesian Council of Islamic Propagation), established in 1967 by Muhammad Natsir, a leading Muslim politician of Masyumi party that was banned by Sukarno in $1960 .{ }^{14}$ Natsir and his proponents basically aspire to Islam as an ideology of the Indonesian state. Because of this, Suharto government had tried to suppress and restrict this group. Meanwhile, the substantialist group, who promote the idea of separating Islam from political parties, is more favourable to the government. Thus, it is not surprising, argues Liddle, that the substantialist ideas had been more widely covered by media than those

11 There is another study of Media Dakwah, which focuses on how the magazine represents its opponents, especially Nurcholish Madjid, in the framework of a Jewish and Christian conspiracy. See Ade Armando (1993). Armando argues that Media Dakwab's coverage is best described as propaganda rather than a press account. This study reminds us that the existence of a print media does not necessarily lead to a healthy dialogue between conflicting parties.

12 For a study of this movement, see Muhammad Kamal Hasan, Muslim Intellectuals Responses to 'New Order' Modernization in Indonesia (Kuala Lumpur: Dewan Bahasa dan Pustaka, 1982).

${ }^{13}$ See for instance Hefner, "Print Islam," note 16.

${ }^{14}$ For a study of DDII, see Asna Husin, "Philosophical and Sociological Aspects of Da'wah: A Study of Dewan Dakwah Islamiyah Indonesia," (Unpublished PhD Thesis, Columbia University, 1998). 
of the scripturalists. ${ }^{15}$ Thus, it is very possible that the animosity of the scripturalists toward the substantialists reflected in Media Dakwah account in 1991-92 is partly because of the political difficulties experienced by the former before 1990s. Liddle eventually argues that if the political situation changes, especially after the resignation of Suharto, the substantialist view will not necessarily win more supporters that that of the scripturalist.

Hefner, more than Liddle's study, discusses the socio-political context of Media Dakwah and its relation to Republika, a newspaper associated with Ikatan Cendekiawan Muslim Indonesia, ICMI (the Association of Indonesian Islamic Intellectuals). Unlike Liddle, Hefner explicitly refers to Habermas' theory of the public sphere. The contest between Media Dakwah and Republika, argues Hefner, "illustrates the centrality of print media in the struggle for public opinion in the Muslim world and the obstacles to developing an open and pluralistic 'public sphere' in situations of authoritarian control."16

To understand the position of Media Dakwah, like Liddle, Hefner discusses in quite some detail the historical and political backgrounds of the DDII. Against these backgrounds, Hefner observes that the message of the magazine is "adamantly anti-humanist and anti-liberal" and portrays Islam as "the uncompromising truth." More importantly, Hefner also tries to find the readerships of Media Dakwah and concludes that "the typical Media Dakwah reader resides in or just outside a city, comes from ranks of the educated lower-middle class or working poor and has developed an interest in the magazine as a result of a personal identification with Masyumi or participation in DDII predication." ${ }^{17}$ In contrast, Republika newspaper tries to attract a wider audience, especially the middle and upper urban middle class. Republika, therefore, features arts, television, literature and fashion

\footnotetext{
15 An important Indonesian magazine, Tempo, has been strongly supportive to Madjid's renewal movement since 1970s. Tempo is non-confessional and secular magazine whose readerships mostly come from middle and upper class. M. Deden Ridwan has studied how Tempo has been involved in promoting Madjid's renewal ideas and his proponents, see M. Deden Ridwan, Neo-Modernisme Islam dalam Wacana Tempo dan Kekuasaan (Jakarta: Belukar, 2002). The book, however, does not sufficiently discuss the relations between Tempo and the New Order government and overlooks the importance of Islamic Student Association [HMI] network within the staffs and editors of Tempo.

${ }^{16}$ Hefner, "Print Islam," p. 79-80.

17 Ibid, p. 91.
} 
trends as well as the idea that Islam is in favour of pluralism and tolerance.

The contrast between the DDII supporters of Media Dakwah and Republika eventually led to successive protests by the former. The DDII supporters said that it is unacceptable that Republika releases some features of art performances that are very 'un-Islamic,' covered the stories on Shi social and political thought and praised the liberal ideas of Ahmad Wahib, one of the exponents of Madjid's renewal movement in 1970s. ${ }^{18}$ Another important clash between the two groups was about the coverage of the attack on the PDI (Indonesian Democratic Party) headquarter known as Suharto's strategy to expel Megawati from her leadership of the party. Although earlier report in Republika on the accident was more sympathetic to the government position, the later government political manoeuvre to accuse a student leftist-oriented organization called Partai Rakyat Demokratik, PRD (People Democratic Party) of being the mastermind behind the riot, and as a communist front group, eventually led the editors of Republika to make a more balanced account. The DDII supporters went on demonstration to Republika office and protested that Republika was in favour of communism. Afterwards, Media Dakwah covered this demonstration and released some articles attacking the communists as the enemy of Islam and the state. Hefner observes that many of his informants believe that this action against Republika was engineered by anti-reform faction in the intelligent services in cooperation with DDII. This incident seems to illustrate what Hefner said in the beginning of this study that an authoritarian state can be a great obstacle to the development of an ideal public sphere.

After the fall of Suharto in 1998 with the increasing freedom of press, there have been a significant number of publications of print and electronic media in Indonesia. One type of the media emerges in this period is those published by the Islamic militants. Hefner carried out a study of media released by an Islamic militant group called Forum Komunikasi Ablussunnah Waljamaah, FKAWJ (Communication Forum for the Followers of Tradition and Community of the Prophet) that established a paramilitary group called Laskar Jihad to fight the

\footnotetext{
18 On Ahmad Wahib, see A. H. Johns, “An Islamic System or Islamic Values? Nucleus of a Debate in Contemporary Indonesia," in William R. Roff (ed.), Islam and the Political Economy of Meaning (Berkeley: Univesity of California, 1987).
} 
Christians in the conflict area of Maluku island. Like in the previous study, Hefner explicitly refers to Habermas' public sphere and argues that "literature on public sphere has provided a useful reminder that the social preconditions for democratisation include not just countervailing powers (although they are important too), but a culture that embraces pluralism and elaborates the terms for public participation."19 The "culture that embraces pluralism," however, cannot be found in FKAWJ media. Thus, Hefner maintains that "modern communications and associations can also be used to exclude minorities and promote public cultures that are anything but civil democratic." 20

FKAWJ was established in 1998 by Ja'far Umar Thalib, an Indonesian of Hadrami-Arab and Madurese parentage. Thalib is a leader who has rich experience in the Middle East: studying in Saudi Arabia and Yemen and getting involved in jiha in Afghanistan. In 1994, Thalib founded an Islamic school called Jama'ah Ibya' al-Sunnah (Community for Reviving the Prophetic Tradition) in Yogyakarta for young adults, especially the university students. A year later, some Thalib's students created a publication called Salafy, thanks to the new desktop-publishing technologies. With the rise of the internet cafés in Indonesia, some graduate students of the Ibya' al-Sunnah living in different cities used this media to communicate each other, including for layout work and editing of the Salafy. The use of media became more intense among FKAWJ activists especially when the organization established its paramilitary wing, Laskar Jihad, in 2000. Hefner found the evidence that Thalib received political and financial supports, for different reasons, from the Indonesian National army officers for Laskar Jihad operations in Ambon. By this time, Laskar Jihad established a website at www.laskarjihad.org in which photo galleries of alleged Christian atrocities, daily news reports on the fighting and

\footnotetext{
${ }^{19}$ Robert W. Hefner, "Civic Pluralism Denied? The New Media and Jihadi Violence in Indonesia," in Dale F. Eickelman and Jon W. Anderson (eds), New Media in the Muslim World: The Emerging Public Sphere, Second Edition (Bloomington: Indiana University Press, 2003), p. 159.

${ }^{20}$ Hefner, "Civic Pluralism Denied?," 160. There is another interesting study, written in a journalist style, about Sabili, a magazine, which also promotes an exclusivist view of Islam vis-à-vis Christian minorities and the West. See Agus Muhammad, "Jihad Lewat Tulisan: Kisah Sukses Majalah Sabili dengan Beragam Ironi,” Pantau. July, no. 015 (2001), or www.pantau.or.id.
} 
stories of other jihadi groups around the world. Laskar Jibad activists also used the internet to send daily reports on the Maluku fight to each of its branches. The reports were downloaded and then printed out on two sided paper entitled Maluku Hari Ini (Maluku Today) and distributed to the public. In addition, Laskar Jihad publishes a weekly bulletin called Buletin Laskar Jihad Ablussunnah Wal-jamaah with full of photos and advertisements. The change of political climate in 2002, however, had pushed Thalib and Laskar Jihad to the margin, especially after the Bali bomb on October 12, 2002. Under a great pressure of the former military supporters, only three days after the bombing, Thalib dissolved the paramilitary group and closed their website. Hefner concludes:

Elite support and the skilful use of media technologies had allowed Laskar Jihad to outflank Indonesia's mainstream Muslim organizations. In so doing, the Laskar Jihad had challenged their moral vision and scaled up a militantly anti-Christian and anti-pluralist interpretation of Islam...[But] media savvy alone could not save them when some in the shadowy coalition of which they had been a part concluded that the Laskar Jihad had become a political liability. ${ }^{21}$

\section{Public Culture, Reasoning and Art}

There are other studies focusing not only on media per se but also and more importantly on public participations and discussions. The works of Robert W. Hefner and John R. Bowen are probably good examples of this kind of study.

In his Civil Islam, Hefner argues that "in many respects, what is happening in the Muslim World resembles what the German sociologist Jürgen Habermas described some years ago as the emergence of the 'public sphere' in the West." Although Hefner agrees with some critiques of Habermas' idealized public sphere model, he contends that "Habermas's analysis has the virtue of emphasizing that democratic life depends not just on government but on resources and habit in society at large". ${ }^{22}$ Hefner argues that among Indonesian society there have been some important Islamic intellectuals with

${ }^{21}$ Hefner, "Civic Pluralism Denied?," p. 175.

22 Robert W. Hefner, Civil Islam: Muslims and Democratisation in Indonesia (Princeton: Princeton University Press, 2000), p. 11; idem., "Public Islam and the Problem of Democratization," Sociology of Religion 62 (2001): pp. 491-514. 
voluntary organization backgrounds (the most frequently mentioned are Nurcholish Madjid, a former leader of Muslim Student Association and the founder of Paramadina Foundation and Abdurrahman Wahid of the traditionalist Nahdlatul Ulama) who have played the role in promoting democratic values in the country. These intellectuals contend that the modern ideals of equality, freedom and democracy are in line with Muslim ideals. The Islamic justification of democracy can be considered ambiguous by those who see that religion should not play a public role in a true democratic society. According to Hefner, in Islamic context, however, this justification is important not only to establish a new public ethic, but also to compete with the conservative notion that Islam is opposed to democracy. ${ }^{23}$ Thus, the public ethic promoted by the Muslim intellectuals in Islamic terms and disseminated within Muslim voluntary associations will in turn pave the way for democracy.

Democracy requires a non-coercive culture that encourages citizens to respect the rights of others as well as to cherish their own. This public culture depends on mediating institutions in which citizens develop habits of free speech, participation and toleration. In all this, they say, there is nothing undemocratic about Muslim voluntary associations (as well as those of other religions) playing a role in the public life of civil society as well as in personal ethics. ${ }^{24}$

Hefner traces back the history of Islam in Indonesia since the period of Islamic kingdoms to the end of Suharto's period and argues that the seed of civil society and civic values has developed since the Islamic kingdoms' period. Hefner, however, does not deny the fact that there are some Muslims who aspire to an Islamic state; a group that he calls "statist" or "regimist" Islam. In contemporary Indonesia, this group comprises a minority. Thus, in the tone of Casanova's public religion theory, ${ }^{25}$ Hefner eventually concludes that:

Despite thirty years of authoritarian rule, Indonesia today is witness to a remarkable effort to recover and amplify a

\footnotetext{
${ }^{23}$ Hefner, "Public Islam and the Problem of Democratization," p. 499.

${ }^{24}$ Hefner, Civil Islam, p. 13

${ }^{25}$ José Casanova, Public Religions in the Modern World (Chicago: Chicago University Press, 1994).
} 
Muslim and Indonesian culture of tolerance, equality and civility. The proponents of civil Islam are a key part of this renaissance. Civil Muslims renounce the mythology of an Islamic state. Rather than relegating Islam to the realm of the private, however, they insist that there is a middle path between liberalism's privatization and conservative Islam's bully state. The path passes by way of a public religion that makes itself heard through independent associations, spirited public dialogue and the demonstrated decency of believers. ${ }^{26}$

If Hefner in his description of Indonesian civil Islam, talks about "public culture," John R. Bowen in his studies of Islam and law in Indonesia, proposes another concept, that is, "public reasoning." Before defining what he means by public reasoning, Bowen refers to some liberal political theories advocated by John Rawls, Will Kymlicka and Joseph Raz who attempt to develop a political theory that can encompass the pluralistic societies. According to Bowen, "their strategies differ, but they all involve trying to arrive at a universal core of principles to which people in all societies can subscribe". 27 This tendency towards a universal core principle is influenced by the liberal assumption that there is a universal rationality with which all people can agree. In this regard, Habermas' notion "that publicity and rationality are intrinsically linked" and that laws in early modern Europe "were understood to flow from a general public consensus" resonates the same tendency. ${ }^{28}$

Based on his anthropological researches, Bowen finds that the universal assumption is contentious. In an article, Bowen said that he is more "interested in internal debates over fundamental questions of cultural values and political community and the processes of reasoning -rather than 'reason'- and justification that defines those debates." 29 In the Indonesian context, according to Bowen:

\footnotetext{
${ }^{26}$ Hefner, Civil Islam, p. 218.

${ }^{27}$ John R. Bowen, Islam, Law and Equality in Indonesia: An Antbropology of Public Reasoning. (Cambridge: Cambridge University Press, 2003), p. 11.

${ }^{28}$ John R. Bowen, "Legal Reasoning and Public Discourse in Indonesian Islam," in Eickelman and Anderson (eds), New Media in the Muslim World, p. 81-2.

${ }^{29}$ John R. Bowen, Shari'a, State and Social Norms in France and Indonesia (Leiden: ISIM, 2001), p. 4.
} 
Public reasoning retains its foundation in comprehensive doctrines, and in particular its foundation in specific understandings of Islam and particular adat based conceptions of the world. The ensuing debates often concern the legitimacy, in Islamic terms, of efforts to interpret religious texts in such a way that they are compatible with other ideals, for example, that of equal treatment of men and women. In these instances, Indonesian Muslims in question endorse, not a political conception of justice as in Rawls, but a reasonable conception of justice that is public and also Islamic (Italics in original). ${ }^{30}$

Now, it seems that Bowen holds the same idea with Hefner's argument that Indonesian Muslims look to religious interpretations by the intellectuals to accept democratic values. However, Bowen's argument is more than that, because for him public reasoning includes "many kind of reasoning processes about justice and rights that contain implications for basic structures of society, and that one finds across all level of society, articulated by village leaders, jurists and judges, national political figures, social activists, and by other ordinary people."31 Thus, Bowen's participants of the public reasoning include different people of different statuses among Indonesian population. ${ }^{32}$

In his exploration of the public reasoning on Islam and law in Indonesia, Bowen finds that people develop different arguments and strategies to answer certain questions. One of the questions is the

\footnotetext{
${ }^{30}$ Bowen, Islam, Law and Equality in Indonesia, p. 11-2.

31 Ibid.

32 Bowen also advocates a similar idea when he discusses Habermas's idea of "public" and "public opinion" in the context of Asia: Yet in Asia the institutional settings for developing public identities have been quite different. In some cases -north India, central Java, urban China- new 'public sphere' initially were elite rather than bourgeois, and grew out of older, shared literate culture...But schools, courtrooms and offices all highly replicable institutions- have provided settings for the emergence of more generally shared identities, perceptions and sentiments across the canvas of colonial and post-colonial spaces, as have religious assemblies and party rallies. In these settings much more than literacy and print involved: classroom interactions, courtroom dialogues, politicians' speeches, and television dramas not only transmit new messages about common public interests, but also create the sense of a wider, listening 'we' in which the listener partakes. See John R. Bowen, "The Forms Culture Takes: A Stateof-the-Field Essay on the Anthropology of Southeast Asia," The Journal of Asian Studies, 54 (1995): p. 1058.
} 
problem of making Islamic family law to be a positive law. Given the fact that there is a variety of figh law in Islamic tradition that may lead to uncertainty and 'disorder', the government effort to make a unified Islamic law was relatively welcomed by Muslims. Nevertheless, another question arises not only in terms of how to overcome figh differences, but also a question as to whether the codified law should conform to the international human rights standard. Bowen traces back the history of Islamic law and finds that there are two tendencies of reasoning in Islamic law: the transcendental and comprehensive. The former is a tendency of reasoning that attempts to understand the divine will embedded in the Qur'a and the $\mathrm{H}\{$ dit that finally lead to a unique divine truth, while the latter is an effort to find a social importance of developing Islamic rules that can be reached through consensus among scholars and/or an accommodation to a political reality. In fact, these two tendencies are complimentary. In the Indonesian case, Bowen finds that the second tendency seems much more at work in the process of making of what is called Compilation of Islamic Law 1991 that includes marriage law, inheritance and pious trust (waqf). It seems a consensus because those who are in charge with this project reportedly had interviewed 166 'Ulama $>$ in ten cities, held seminars and workshops attended by professors of religious law, jurists, judges and Supreme Court justices. Finally, through a journal called Mimbar Hukum, the intellectuals of the Department of Religion argue that the

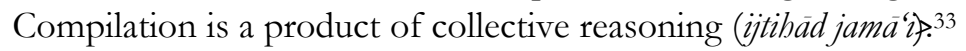

The consensus, however, is still questioned. One of the controversies around the Compilation was concerning gender equality in inheritance law. Minister of Religion, Munawir Sjazdali and some progressive scholars and feminists argue that the Islamic traditional idea stipulated in the Qur'athat female inheritor gets half of the male one should be changed into an equal share. These people develop different types of reasonings to support this idea. Some argue through historical analysis of Islam in Saudi Arabia and then back to modern Indonesia to show the differences and at the same time to argue for the equality of man and woman as a general principle of Islam. Others look to local custom and argue for an 'Indonesian sense of justice,' while others invite us to see the discrepancy between discourse and practice and the 'hypocrisy' of the 'Ulama who try to maintain the law

${ }^{33}$ Bowen, "Legal Reasoning and Public Discourse," p. 83-97. 
of un-equality but at the same time distribute their property equally among their male and female family. Many conservative 'Ulama'? however, disagree with the proposed change and therefore the Compilation still maintains the two-to-one ratio. In addition, the Compilation adds another sentence: "the judge must take into account the values and the living law among the people." 34

What is the living law among the people? This question takes us into another public reasoning in Bowen's study, that is, the relationship between local custom and Islamic law. In his study of the Gayo people of Aceh in North Sumatera, Bowen gives us a very rich account of public reasoning inside and outside the court involving the interaction between local custom and Islamic law. One of the examples demonstrated in the study is the inheritance dispute. According to Gayo tradition, any son or daughter who gets married to a person outside the village, he or she will not be entitled to the estates left by his/her parents. A woman went to Islamic court in 1960s to get a share of land controlled by her brother in the village. According to Islamic law, the woman can get her share, but the judges tried to avoid the contradiction between local norms and Islamic law by arguing that there was a consensus regarding the estate some years ago and the woman just kept silent (which meant she agreed with decision). Thus, there is no point to reopen the case in the court! A similar case, however, was judged differently in 1990s. The judges now asked both the plaintiff and defendant if there was really a consensus among the family and/or if they can make an agreement outside the court. Otherwise, the judge will enforce the Islamic norm. This change can be understood, Bowen argues, if we look at the socio-political change of Gayo land in particular and Indonesia in general. In 1990s, the Islamic court had already had the authority to settle inheritance cases and there was a Compilation of Islamic Law of 1991 as the reference for the court. Furthermore, social mobility of the local people had increased during this period and the idea that to be a member of a village means to live in the area had gradually diminished. With the increase of the central government control of the Islamic court, the judges in Gayo land who happened to be the local people, now had

\footnotetext{
${ }^{34}$ John R. Bowen, "Qur'an, Justice, Gender: Internal Debates in Indonesian Islamic Jurisprudence," in History of Religion. 38 (1998), pp. 52-78; idem., Islam, Law and Equality in Indonesia.
} 
been replaced by other people who did not really understand the local custom..$^{35}$

Another study which tries to analyze Indonesian Islam as it appeared in the public sphere is the work of Kenneth M. George. ${ }^{36}$ This American scholar pays his attention to a politico-cultural event held in 1995 in Jakarta called "Festival Istiqlal 2". In Arabic, "istiqlal" simply means "independence", but its meaning becomes more exclusively Islamic in Indonesian context because it is the name of the national mosque in Jakarta. The festival, therefore, was held not only in relation to the fiftieth anniversary of Indonesian independence but also to the programs of the festival which were focused on Indonesian Muslim culture. Unlike "Festival Istiqlal 1" that was held in 1991, this second festival has something special called "Al-Qur'an Mushaf Istiqlal," an artistic work of calligraphy of the Qur'a consists of 970 pages, and $123 \times 88$ centimeter in size.

George found that the mush fof was an important materialization of the contest between Islam and the state in the public sphere. As many observers indicate, by early 1990s, Suharto shifed his political alliance from the nominal Muslims (abangan) and Christians to the Islamic groups (santri), especially the reformist one. During his rule, in imitation of the Dutch colonial policy, Suharto tried to depoliticize Islam and push it strictly to "the cultural corner". The Mushaf Istiqlal, according to George, represents the struggle between Suharto and the Islamic groups for realizing their respective agendas. It was clear that Suharto wanted to use Islam for his ambition to stay in power, and at the same time he never tolerated any ideological ambition of the Islamic groups. Therefore, when the president agreed to support the festival, he urged that it should be a festival of Indonesian culture inspired by Islam. It means that "nationalist aspirations and sensibilities had to precede and be served by religious ones". ${ }^{37}$

On the other hand, the artists who made the mush 3 f), tried "to summon fort an Indonesian Muslim public around a civic and cultural project, and to alert that public to its own spiritual and artistic

\footnotetext{
${ }^{35}$ Bowen, Islam, Law and Equality in Indonesia, pp. 89-122.

${ }^{36}$ Kenneth M. George, "Designs on Indonesia's Muslim Communities," The Journal of Asian Studies, 57 (1998), pp. 693-713.

${ }^{37}$ Ibid, p. 702.
} 
activity". ${ }^{38}$ In other words, the artists working for the project did not only work to create an aesthetic object, but also and more importantly to represent Islam in the Indonesian national public sphere. To do this, they tried to include 42 Muslim cultures and design areas of Indonesia, and put them together in the margin decoration of the mus ly 2$\}$. The 42 design areas were certainly arbitrarily decided by the artists, and this also triggered criticisms because some areas known as non-Islamic regions like Bali, Papua and East Timor were also included.

The Mushaf Istiqlal, therefore, represents the interests of the state as well as the Muslim artists in the public sphere. George then concludes that "while the state dominates the public sphere, certain figures can exploit its intrusions for their own social, cultural or religious ends, and in that sense, find room for manoeuvre even within the most repressive political system". ${ }^{39}$ Moreover, the mush if case also shows us the intricate issue of Islam and the modern nation state. In this context, the important question in the Indonesian public sphere, said George, is: "What political embrace is to be desired when a nation state has designs on its Muslim communities, and those communities have designs on the nation-state?"40

\section{Competing Publics and Variety of Reasonings}

The studies summarised above show us different kinds of analysis and focus that may guide us to see if the concept of 'public sphere' is a useful category to understand Indonesian Islam. One of the obvious facts demonstrated in these studies is that there are competing publics rather than one single public of bourgeois public sphere introduced by Habermas. Geoff Eley argues that there were other important public spheres even in the nineteenth century of Europe other than that of bourgeois class. ${ }^{41}$ Nancy Fraser argues further that the existence of competing publics, either in stratified or egalitarian multicultural societies, is necessary to develop a participatory democracy. This does not mean that we "preclude the possibility of an additional, more

\footnotetext{
38 Ibid, p. 709.

39 Ibid, p. 710.

40 Ibid, p. 711.

41 Geoff Eley, "Nations, Publics and Political Cultures: placing Habermas in the nineteenth century," in Nicholas B. Dirks et al. (eds), Culture/Power/History: A Reader in Contemporary Social Theory (Princeton: Princeton University Press, 1994).
} 
comprehensive arena in which members of different, more limited public talks across lines of cultural diversity." 42

Obviously the existence of the competing Muslim publics supports the thesis that new media in the Muslim World leads to a fragmentation of religious authority. ${ }^{43}$ However, far from the expectation of these scholars, the above study shows us that the new media do not necessarily lead to new lay-interpreters of Islam but on the contrary the media help reinforce the existing different religious authorities. The figures in DDII, Ja'far Umar Thalib of FKAWJ as well as Wahid and Madjid are the Islamic leaders whose authorities have been strengthened, rather than weakened by the media. On the other hand, in George's study we find that the artists apparently played more significant role in the making of the Mushaf Istiqlal than the 'Ulama?

The plurality of publics also urges us to think of the importance of the range of participation in the public sphere. Perhaps, the contrast between the more simple analysis and scope of Federspiel's study that does not consider sufficiently the voices of the others beyond alMuslimun, compared to Liddle's, Hefner's and Bowen's studies, may show us at first glance that the idea of public sphere in which people interact and argue for or against one another is more helpful to understand our object of study. The assumption is, the more participants and scope we cover, the more understanding we get. ${ }^{44}$ There are at least two types of participants: those who are directly

\footnotetext{
42 Nancy Fraser, "Rethinking the Public Sphere: a Contribution to the Critique of Actually Existing Democracy," in Craig Calhoun (ed), Habermas and the Public Sphere (Cambridge: MIT Press, 1992), pp. 121-28.

43 Francis Robinson, "Technology and Religious Change: Islam and the Impact of Print," Modern Asian Studies, 27 (1993), pp. 229-51; Eickelman and Anderson, "Redefining Muslim Publics"; Peter Mandaville, Transnational Muslim Politics: Reimagining the Umma (London: Routledge, 2001).

${ }^{44}$ It is also important to look at various media that are available in Indonesian public life. Today, the use of internet has gradually developed among urban middle class. We can usually find internet cafés in major cities around the country. There are also some Islamic and Christian homepages, besides the non-confessional ones. Visit for instance, www.hidayatullah.com; www.islamlib.com; www.gerejakatolik.net; www.bahana-magazine.com. Another popular media -used by Muslims and others alike- is VCD. We can find a lot of VCDs on religious music, preaches, and Muslim-Christian tensions. Last, but not least, almost all TV stations in Indonesia have an Islamic preaching program, which is usually broadcasted in the morning. These are certainly interesting resources for scholarly research on Indonesian Islam.
} 
involved in debates and discussions as writers or speakers; and those who just read and listen to the former. If we look at Indonesian statistics, we can assume that during and after Suharto period (Liddle's, Hefner's, Bowen's and George's studies) there had been likely more participants than that of Sukarno period (Federspiel's study) because of educational improvement in the former period. Hefner, with reference to Gavin W. Jones and Chris Manning mentions that the basic literacy skill of young adults sharply increased from 40 percent in 1965 to 90 percent in 1990s. ${ }^{45}$ There was also a dramatic increase of the number of people completing senior high school from 4 percent in 1970 to more than 30 percent in 1990.

However, even the studies focused on the Suharto period and afterwards have different degrees of participant-coverage. Both Hefner's and Liddle's studies, for instance, mostly focus on intellectual Muslim discourses and politics in Jakarta. ${ }^{46}$ According to some recent critiques of Hefner's Civil Islam, this study even pays more attention to the elite intellectuals such as Nurcholish Madjid and Abdurrahman Wahid and thereby overlooks the gap and differences between these figures and their colleagues inside and outside their organizations. ${ }^{47}$ We may assume that Jakarta national elites have more significant influence on politics and publics, but it does not mean that the ideas and politics developing in the outer islands are not significant at all.

\footnotetext{
${ }^{45}$ Hefner,"Civic Pluralism Denied?," p. 163.

46 The limit of the scope can also be found in terms of Media Dakwah circulation. The magazine only had a limited license called STT (Surat Tanda Terdaftar), not the general publishing license called SIUPP (Surat Izin Usaba Penerbitan Press). This means that it is not allowed to distribute the magazine for general sale. It can only be distributed among a limited circle such as members of an organization. Media Dakwah finally obtained the SIUPP in February 1998 due to the help of - as it was widely believedGeneral Prabowo Subianto, Suharto's son in law. See Hefner "Print Islam," p. 91; idem., Civil Islam, p. 253 and note 37). Thus, by the time of Liddle's and Hefner's studies, the circulation of the magazine was very limited. For Media Dakwah, Hefner estimates about sixteen to eighteen thousand copies per issue and about twenty five thousand copies for a hot issue. This number is very low compared to a more recent achievement of bimonthly Sabili, another Islamist magazine that reached 80 thousand copies in the year 2000 and even 100 thousand copies in 2001 per issue. See Muhammad, "Jihad Lewat Tulisan."

${ }^{47}$ Martin van Bruinessen, "The Threat to 'Smiling Islam," Times Literary Supplement (October 12, 2001), p. 27; John T. Sidel, “It Takes a Madrasah?': Habermas Meets Bourdieu in Indonesia," South East Asia Research, 9 (2001), pp. 109-22.
} 
Nevertheless, Bowen's studies, to some extent, have filled this gap through his analysis of the views of both national Jakarta-based intellectuals and politicians and local figures in Gayo region. Unlike the other studies, Bowen also includes women voices in his discussion. In this regard, I think that Bowen's scope of study can be extended further to non-Muslim groups, especially the Christians whose positions and views are important to consider, especially those issues involving both religious groups. Bowen for instance argues that recent development of Islamic law in Indonesia has strengthened religious boundaries in society, especially between Muslims and Christians. ${ }^{48}$ His account, however, only gives us mostly on Muslim side, not the other. In fact, the problems of inter-religious marriage and the controversy on Marriage Law 1974 for instance, have been very much discussed and debated among Christians as well (not to mention the recent Education Law and the Inter-Religious Harmony Law draft). ${ }^{49}$ This extended scope will not only help us understand the internal reasonings (to use Bowen's term) within each religious groups on the same issue, but also may assist us to see how these groups talk in a common arena where they should resolve the conflicts and differences.

Another important point is that the competing publics described in the studies have tried to support their respective positions by developing a certain type of argument that to a certain degree can be considered rational. But, it is not a pure rationality in Kantian sense (followed by Habermas) to which everybody is assumed will submit if he or she relies solely on reason. ${ }^{50}$ The reason is, as Hefner and Bowen argue, Indonesian Muslims look to their religious traditions to formulate their ideas. This is why Bowen prefers using the term "reasoning" to "reason." Thus, we may say that this type of reasoning

\footnotetext{
48 Bowen, Islam, Law and Equality in Indonesia, pp. 229-52.

49 Bowen wrongly says that "A law on 'inter-religious harmony (kerukunan antar-agama) recently has been under parliamentary discussion" and that the joint decree of Ministers of Religion and Interior forbidding any effort to convert people who had already adhered to one of the recognized religions was issued in 1970. See Bowen, Islam, Law and Equality in Indonesia, p. 239. The inter-religious harmony law has not been brought to parliament discussion yet (although it has been discussed both in the Department of Religion and Christian and Muslim media) and the joint decree was issued not in 1970 but in 1979 .

${ }^{50}$ Craig Calhoun, "Introduction: Habermas and the Public Sphere," in Craig Calhoun (ed.), Habermas and the Public Sphere (Cambridge: MIT Press, 1992), p. 2.
} 
is different from Charles Taylor's notion that when people discuss common interest in the public sphere they will not refer to any metaphysical concepts transcending contemporary common action. ${ }^{51}$ Nevertheless, the absence of radical secularity (to use Taylor's term) in Indonesian Muslim debates, according to Hefner and Bowen, does not necessarily mean that they are not concerned with common interest of the public. In this regard, Bowen's analysis of different reasonings by different publics shows us that his understanding of Islamic traditions on methods of reasonings is very significant. Instead of drawing a simple and common dichotomy between traditionalist and reformist or substantialist and scripturalist, based on his knowledge of figh tradition, Bowen can explore deeply the complexities and differences among Muslim public reasonings.

Last but not least, the above studies show us that the state, especially the military, is a very important variable behind the public discursive contestations. This fact seems to lead Hefner to argue that civil society cannot smoothly develop without the support of a civil state. Thus, public sphere as a domain for the development of civil society cannot be sharply separated from the state as such. Based on certain political circumstances, Suharto regime had supported directly or indirectly either Madjid's group or Media Dakwah's group. George's study of the Mushaf Istiqlal illustrates another important point, namely that even under the Suharto's authoritarian regime, which strictly tried to control the whole society, there was still a space where the Muslims could represent their interests in the public sphere.

In this regard, it is probably interesting to look at Fraser's theory of strong and weak publics. Publics are strong if they are involved in both formation opinion and decision making process and considered weak if they are involved only in opinion formation. Parliament is a good example of a strong public. Fraser also considers self-managing institutions as strong publics if they become the arenas of both opinion formation and decision making. ${ }^{52}$ This theory may help us understand better when a certain issue becomes a discursive contestation in the public sphere in Indonesia. For instance, the controversies on Marriage Law and Education Law in Indonesia that

\footnotetext{
${ }^{51}$ Charles Taylor, "Modernity and the Rise of the Public Sphere," The Tanner Lectures on Human Values, 14 (1993), pp. 203-60.

${ }^{52}$ Fraser, "Rethinking the Public Sphere," pp. 134-5.
} 
finally led to a certain type of decision (favouring Muslim majority but at the same time compromising Christian minority) might be best understood through this theory.

\section{Conclusion}

Having discussed the relevant studies on Islam and the public sphere in Indonesia and analysed them through some scholarly discussions on this issue, we may conclude that it can be fruitfully used and developed for further research. The idea of public sphere urges us to cover more participants who are involved in discussing a public issue. This will include both national and regional figures with different statuses and religious backgrounds. This wider coverage will also urge us to learn the relevant Islamic traditions in order to have a better understanding of the variety of reasonings within the competing publics.

Our analysis of the studies also shows us that there are differences between Habermas' understanding of public sphere and its application in the studies of Indonesian Islam. Habermas' notion of a single, rational and secular public sphere is certainly different from the public sphere described in the above studies which is plural and still within the domain of Islamic reasonings. The studies also illustrate that the widespread of media in Indonesia has led to more fragmented religious authorities but at the same time also strengthened the existing religious authorities. I a few cases, we also find the emergence of non- 'Ulama> as the speakers of Islam. Finally, the studies also reveal the intricacy of the relationships between the state and the public sphere. Rather than making a clear-cut line between the two, it will be more useful to look at the dynamic interactions between them. In fact, the socio political forces operating in the public sphere are not the simple dichotomy of state and society, but there are different local, national, and international forces, which influence the public sphere.]

\section{Bibliography}

Armando, Ade.. "Citra Kaum Pembaru Islam dalam Propaganda Media Dakwah." Ulumul Qur'an, 4 (1993): pp. 66-76.

Bowen, John R. "The Forms Culture Takes: A State-of-the-Field Essay on the Anthropology of Southeast Asia." The Journal of Asian Studies, 54 (1995): pp.1047-78. 
- "Qur'an, Justice, Gender: Internal Debates in Indonesian Islamic Jurisprudence.” History of Religion, 38 (1998): pp.52-78.

-."Legal Reasoning and Public Discourse in Indonesian Islam," in Dale F. Eickelman and John W. Anderson (eds). New Media in the Muslim World: the Emerging of Public Sphere. Bloomington: Indiana University Press, 1999.

. Shari'a, State and Social Norms in France and Indonesia. Leiden: ISIM, 2001.

-------. Islam, Law and Equality in Indonesia: An Anthropology of Public Reasoning. Cambridge: Cambridge University Press, 2003.

Bruinessen, Martin van. "The Threat to 'Smiling Islam." Times Literary Supplement. October 12, 2001: p. 27.

Calhoun, Craig. "Introduction: Habermas and the Public Sphere," in Craig Calhoun (ed). Habermas and the Public Sphere. Cambridge: MIT Press, 1992.

Casanova, José. Public Religions in the Modern World. Chicago: Chicago University Press, 1994.

Eickelman, Dale F. and John Anderson. "Redefining Muslim Publics," in Dale F. Eickelman and Jon Anderson (eds). New Media in the Muslim World: The Emerging Public Sphere. Bloomington: Indiana University Press, 1999.

Eley, Geoff. "Nations, Publics and Political Cultures: placing Habermas in the Nineteenth Century," in Nicholas B. Dirks et al. (eds). Culture/Power/History: A Reader in Contemporary Social Theory. Princeton: Princeton University Press, 1994.

Federspiel, Howard M. "The Political and Social Language of Indonesian Muslims: The Case of al-Muslimun." Indonesia, 38 (1984): pp. 55-73.

--------. Islam and Ideology in the Emerging Indonesian State: the Persatuan Islam (PERSIS) 1923-1957. Leiden: Brill, 2001.

Fraser, Nancy. "Rethinking the Public Sphere: a Contribution to the Critique of Actually Existing Democracy," in Craig Calhoun (ed.). Habermas and the Public Sphere. Cambridge: MIT Press, 1992. 
George, Kenneth M. "Designs on Indonesia's Muslim Communities." The Journal of Asian Studies, 57 (1998): pp. 693-713.

Habermas, Jürgen. The Structural Transformation of the Public Sphere: An Inquiry into a Category of Bourgeois Society. trans. by Thomas Burger and Frederick Lawrance. Cambridge: Polity Press, 1989.

Hasan, Muhammad Kamal. Muslim Intellectuals Responses to 'New Order' Modernization in Indonesia. Kuala Lumpur: Dewan Bahasa dan Pustaka, 1982.

Hefner, Robert W. "Print Islam: Mass Media and Ideological Rivalries Among Indonesian Muslims.” Indonesia, 64 (1997): pp.77-103.

-------. Civil Islam: Muslims and Democratisation in Indonesia. Princeton: Princeton University Press, 2000.

--------. "Public Islam and the Problem of Democratization." Sociology of Religion 62 (2001): pp. 491-514.

. "Civic Pluralism Denied? The New Media and Jihadi Violence in Indonesia," in Dale F. Eickelman and Jon W. Anderson (eds). New Media in the Muslim World: The Emerging Public Sphere, Second Edition. Bloomington: Indiana University Press, 2003.

Husin, Asna. "Philosophical and Sociological Aspects of Da'wah: A Study of Dewan Dakwah Islamiyah Indonesia." Unpublished $\mathrm{PhD}$ Thesis, Columbia University, 1998.

Johns, A.H. "An Islamic System or Islamic Values? Nucleus of a Debate in Contemporary Indonesia," in William R. Roff (ed.). Islam and the Political Economy of Meaning. Berkeley: Univesity of California, 1987.

Liddle, R. William. "Media Dakwah Scripturalism: One Form of Islamic Political Thought and Action in New Order Indonesia," in Mark R. Woodward (ed.). Toward a New Paradigm: Recent Developments in Indonesian Islamic Thought. Tempe: Arizona State University, 1996.

Mandaville, Peter. Transnational Muslim Politics: Reimagining the Umma. London: Routledge, 2001.

Muhammad, Agus. "Jihad Lewat Tulisan: Kisah Sukses Majalah Sabili dengan Beragam Ironi," Pantau. July, no. 015 (2001). or www.pantau.or.id 
Mujiburrahman

Ridwan, M. Deden. Neo-Modernisme Islam dalam Wacana Tempo dan Kekuasaan. Jakarta: Belukar, 2002.

Robinson, Francis. "Technology and Religious Change: Islam and the Impact of Print." Modern Asian Studies, 27 (1993): pp. 229-51.

Sidel, John T. “It Takes a Madrasah?’: Habermas Meets Bourdieu in Indonesia." South East Asia Research, 9 (2001): pp.109-22.

Taylor, Charles. "Modernity and the Rise of the Public Sphere." The Tanner Lectures on Human V alues, 14 (1993): pp. 203-60. 